\title{
Perception of Women on Commercialisation of the Nigeria-Canada Indigenous Vegetables Project in Southwestern Nigeria
}

International Journal of Economics, Business and Management Studies

Vol. 8, No. 1, 13-23, 2021

e-ISSN: 2226-4809/p-ISSN: 2304-6945

check for

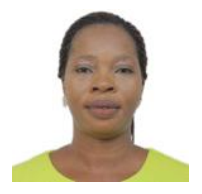

\author{
Adijat Bola ADENIYI \\ Department of Business Administration, Faculty of Humanities, Management and Social Science \\ Kings University, Odeomu, Osun State Nigeria. \\ Email:fiyinfoluwa2009@yahoo.com Tel:+234-08138936110
}

\section{ABSTRACT}

The paper investigated the perception of women toward the commercialisation of the NICANVEG indigenous vegetables project. A survey research design was used for the study. Samples of 390 women (300 for quantitative and 90 for qualitative) were used for the study. The samples were selected from three out of the four states in Southwestern Nigeria where the project took place between 2011 and 2014. Two adapted instruments titled "Questionnaire on NICANVEG Project and Commercialisation (QNPC)" and "Interview on NICANVEG Project and Commercialisation" (INPC) were used to collect data. Data collected were analysed using percentages, relative significant index, chi-square and software package (Atlas ti) statistical analyses. The results showed that $182(60.7 \%)$ of the women expressed a positive perception towards the commercialisation of the product. It was showed that the extent of involvement of women in the commercialisation indicated that $78.0 \%$ of the women participated in full-scale commercialisation of NICANVEG indigenous vegetables. Again, the result showed the major challenges facing commercialisation of the vegetables were expensive farm equipment $(\bar{X}=3.57$, RSI $=0.719)$, untimely fund $(\bar{X}=3.53$ RSI $=0.711)$ and poor market prices of vegetables $(\bar{X}=3.32$, RSI $=0.666)$. Above all, the result showed a significant relationship between levels of participation in the training on NICANVENG indigenous vegetables project and the extent of commercialization of the product $\left(\chi^{2}=111.865, \mathrm{p}<0.05\right)$. The study concluded that positive perception of the participants had enhanced the commercialization of the indigenous vegetables.

Keywords: Perception, Women, Commercialization, Indigeneous, Vegetables, NICANVEG.

JEL classification: MOO.

DOI: $10.20448 / 802.81 .13 .23$

Citation | Adijat Bola ADENIYI (2021). Perception of Women on Commercialisation of the Nigeria-Canada Indigenous Vegetables

Project in Southwestern Nigeria. International Journal of Economics, Business and Management Studies, 8(1): 13-23.

Copyright: This work is licensed under a Creative Commons Attribution 3.0 License

Funding: This study received no specific financial support.

Competing Interests: The author declares that there are no conflicts of interests regarding the publication of this paper.

History: Received: 25 June 2021 / Revised: 29 July 2021/ Accepted: 23 August 202 1/ Published: 16 September 2021

Publisher: Online Science Publishing 


\section{Highlights of this paper}

- The paper investigated the perception of women toward the commercialization of the NICANVEG indigenous vegetables project.

- The paper revealed that most women who actively participated in the training on NICANVEG indigenous vegetables project developed a positive perception towards the commercialisation of the indigenous vegetables.

- The paper recommended that the government and other stakeholders can assist farmers by providing constant agricultural extension services to women farmers.

\section{INTRODUCTION}

The economic role of women in every family is very important. They contribute numerous ideas and a great deal of energy and capital resources to their communities and families through their involvement in businesses. The monies made by women are largely spent to take care of household needs. Regardless of this, women's economic empowerment, especially in rural areas, is facing many challenges. In spite of many initiatives and projects initiated by both the government and non-governmental agencies, the actual situation is far from desirable. In his reaction, Acha (2014).

country. This has made many rural women remain dependent and lack the means to achieve economic independence in the families and communities at large.

Globally, women were believed to contribute remarkably to the rural economy and agricultural activities in many developing countries (FAO, 2010a). According to the reports of FAO (2010b) the agricultural share of economically active women were $65.0 \%$ in Sub-Saharan Africa in 2010, while in Nigeria the agricultural share of economically active women was reported to be 26.8\% in 2010. Also, World Bank (2007) believed that women are the majority of smallholder farmers, but fail to realise their full potential in agriculture contributed to low growth and food insecurity. For instance, Anon (2006) indicated that women are responsible for carrying out $70 \%$ of agricultural labour, $50 \%$ of animal husbandry related activities and $60 \%$ of food processing activities

In Nigeria, agriculture was the most important sector of the economy from the standpoint of rural employment, sufficiency in food and fibre, and export earnings prior to the discovery of oil. The agricultural sector was still the leading sector in Nigeria's ailing economy. It provided direct employment to about $75 \%$ of the population (National Bureau of Statistics, 2014). Unlike what used to be in the 70 s and 80 s when agriculture contributed about twothirds of the country's Gross Domestic Product (GDP) presently, agriculture contribution to Nigeria's GDP is about $37.2 \%(\mathrm{CBN}, 2006)$.

Nigerian-Canada Vegetable Project (NICANVEG) was a research project jointly partnered by some researchers from Obafemi Awolowo University and Osun State University, both in Nigeria, and University of Manitoba and Cape Breton University from Canada. The NICANVEG project was funded by the International Development Research Centre (IDRC) and the Government of Canada provided through Foreign Affairs, Trade and Development Canada (DFATD) and the project was initially staged for three years, between 2011 and 2014 in four administrative states in Southwestern Nigeria (Osun, Oyo, Ekiti and Ondo) with 22 registered cooperative societies comprising 1,200 farmers (600 males and 600 females) who were given some financial aids and inputs in order to show interest in the cultivation of indigenous vegetables (International Development and Research Centre (IDRC), 2014). Some of the vegetables identified for the project included: Telfairia occidentalis (Ugwu), Solanum macrocarpon (Igbagba), Amaranthus viridis (Tete atetedaye) (International Development and Research Centre (IDRC), 2014).

Today, the importance of African indigenous leaf vegetables and fruits to human nutrition, medicine and nature in Southwest, Nigeria is expected to be realised through the intervention of NICANVEG project. Since its 
inception, the project has created awareness on the usefulness of ten under-utilised indigenous vegetables (UIVs), namely African eggplant (Solanum macrocarpon), African nightshade (Solanum nigrum), Woorowo (Solanecio biafrae), Amaranth (Amaranthus viridis), Fluted pumpkin (Telfairia accidentalis), Scarlet eggplant (Solanum scabrum), Field pumpkin (curcubita pepo), Fire wood (Crassocephalum crepidoides), Bitter leaf (Vernonia amygdalina) and Snake Tomato (Trichosanthes cucumerina) commonly consumed in Southwest, Nigeria. With the introduction of NICANVEG, it is possible to have redirected the attention of the rural farmers to the production, marketing, consumption and nutritional awareness of under-utilised indigenous vegetables.

With the introduction of NICANVEG project, it was expected that the women through their participation in the project would have a great opportunity to embrace the new technologies that could enhance their movement from subsistence farming to more market-oriented system cultivation of indigenous vegetables known as commercialisation. Therefore, commercialisation in agriculture, according to Sokoni (2007), could be defined as a process involving the transformation from production for household subsistence to production for market purposes. To Immink and Alacorn (1993), commercialisation is the proportion of agricultural production that is brought to the market for sale. Also, Olwande, Smale, Mathenge, Place, and Mithöfer (2015) saw commercialisation in agriculture as the steady departure from the domestic production for auto-consumption to mass production with the aim of selling in the market. Through this system., the women would have their revenue generated being boosted and their standard of living being improved. However, it was not certain the extent to which women who participated in the NICANVEG project have adopted it and shifted from household production of the vegetables to commercial purposes.

In the meantime, the extent of commercialisation of indigenous vegetables among Sub-Saharan Africa countries especially in Nigeria was seen as a crucial role in poverty alleviation. Edeoghon (2016) explained that the commercialisation of indigenous vegetables was being given less attention in Nigeria. Based on this, in the past, researches had been carried out on the extent of commercialisation of indigenous vegetables in Nigeria. For example, Okezie, Nwosu, and Okezie (2008) assessed the commercialisation of agriculture in Abia State, Nigeria. The study identified three concepts under which household subsistence or commercial orientation could be quantified. The first concept, agricultural subsistence orientation measured the extent to which farm households consumed out of their aggregate agricultural produce while the second and third, look more broadly at subsistence orientation at the income generation side and consumption side. They concluded that agriculture was not subsistence-oriented in terms of the value of agricultural produce that is for the market. Households that were most subsistence-oriented earned less in terms of off-farm income compared to those that were least subsistence oriented.

Furthermore, Shiundu and Oniang'o (2007) study established that the market share of African indigenous leafy vegetables (ALVs) in comparison with other vegetable species have been on the upward trend, in the urban markets and increased consumption in rural areas too. However, issues of quality control, reliability and pricing remained critical to the future success of ALVs farming. Women have been closely associated with the cultivation and selling of ALVs; however, studies have shown that whenever a crop began to appreciate in the market and started fetching higher income, men tended to push their way into the trade. In a similar vein, a study conducted by Nizamuddin, Salman, and Rehman (2009) revealed that vegetables were remunerative crops and that farmers, particularly men, tended to turn towards its production as it was known to generate quick income for sustenance.

Also, Ele, Omini, and Adinya (2013) determined the extent of the commercialisation of vegetables in Cross River State, Nigeria. The study identified the variation in the level of commercialisation among households in the three agricultural zones and identified the micro-level factors determining the level of commercialisation. Findings 
showed that the degree of commercialisation in the study area was moderately high (about 60.40\%). On average, households sold about $56.10 \%, 66.60 \%$ and $58.50 \%$ of their total production (in grain equivalent terms) for the Southern, Central and Northern zones respectively.

Meanwhile, In Nigeria and in other developing countries, farmers who practice at the subsistence level find it difficult to practice full commercialisation of their products because of the range of challenges and barriers which have reduced their intention for full participation. Empirical findings have given credence to some of the challenges. For instance, According to Mary (2007), some of the major constraints facing the production of indigenous vegetables in western Kenya, were poor seed quality, pests and diseases, drought, poor marketing channels, transport to markets, lack of agronomic and utilisation packages were among the major constraints that hindered optimal production of African leafy vegetables. Seed quality was normally affected by the agronomic practices used, the time of harvest and seed processing procedures. Judging from the above, it is unequivocal to state that nonavailability of good seedling could be a great threat to the commercialisation of indigenous vegetables.

In addition, Agboola (2001) saw the availability of credit source, high cost of inputs, irregular fuel supply, irregularity in water pump operation and frequent breakdown of water pump as constraints facing vegetable farmers in Remo Local Government Area of Ogun State.Also, Adelani, Olajide-Taiwo, Adeoye, and Olajide-Taiwo (2011) identified credit facilities and inputs as the major challenges of vegetable farmers in Oyo State, Nigeria. Sabo and Dia (2009) identified the use of crude implements, non-availability of inputs, illiteracy, expensive and complex technologies as constraints facing vegetable farmers in Nigeria.

Besides, Leavy and Poulton (2007) identified access to staple foods and asset accumulation as critical factors that determined the success of agricultural commercialisation among smallholders. Also, Mahelet (2007) found several factors that can either facilitate or constrain the commercialisation of African leafy vegetables in Ethiopia. These factors included, among others, distance to the market, access to transportation services and roads; availability of credit, extension services and market information; output, input and factor prices; land size, access to modern inputs and storage facilities; and integration into output markets. The above results were supported by the reports of the studies conducted by the World Bank (2007) and Deji, Koledoye, and Owombo (2012) who identified non-availability of land, the inadequacy of inputs, lack of extension contact, transportation, storage, high cost of input as constraints facing men and women vegetable farmers but at different degrees; which was attributed to the differences in roles and responsibilities of each gender along with the vegetable production chain.

Again, the study conducted by Lyatuu et al. (2009) indicated that there was an increase in demand for indigenous vegetables in Tanzania, Botswana and Zambia. On the other hand, indigenous vegetables were at risk of being eroded in these countries, as farmers were replacing them with improved varieties. The reason was the lack of seed and information about their performance, input requirements and marketing. It was also indicated that indigenous vegetables marketing was characterised by inadequate government intervention. The challenges that farmers were facing were a lack of reliable market information, market advisory service providers and a lack of pricing mechanism. Farmers sold their products just to cover their cost of living, rather than considering their production cost, supply and demand conditions. The highly perishable nature of indigenous vegetables created a major challenge in distribution and marketing.

Moreover, Muriithi and Matz (2015) examined the factors responsible for the participation of smallholders in commercial horticultural farming in Kenya. The study employed panel survey data on smallholder producers of both international (export) and indigenous vegetables sold in domestic market and controls for unobserved heterogeneity across farmers. The study found out that the participation of smallholders in both the domestic and export vegetable markets declined and that this trend was associated with weather risks, high costs of inputs and 
unskilled labour, and erratic vegetable prices, especially in the international market. Again, the study established that different factors were at play in determining a household's market choice for the commercialisation of vegetables: credit facilities was important only when vegetables were (also) exported and distance to the nearest market town positively related to all pathways of commercialisation.

Finally, Pandit and Basak (2013) study was conducted to determine the constraints facing the farmers in commercial cultivation of vegetables and to the explore relationship between the selected characteristics of the farmers and constraints faced by them. The researchers conducted personal interview on 142 randomly selected respondents out of 1422 vegetable farmers. The results showed that low price of vegetables during harvesting ranked first followed by lack of quality seed and high wages of labourers. Among the ten selected characteristics, level of education, family size, farm size, extension media contact, knowledge on vegetable production and cosmopolites showed significant negative correlation and family subsistence the pressure showed a significant positive correlation with farmers' constraints in commercial cultivation of vegetables. Consequent to the points raised above, it is expedient to investigate the perception of women toward the commercialisation of the NigeriaCanada indigenous vegetables vis-à-vis the challenges being faced by the farmers in the commercialisation of the product.

\section{OBJECTIVES OF THE STUDY}

a. Investigate the perception of women toward the commercialisation of the Nigeria-Canada indigenous vegetables project in Southwestern Nigeria.

b. Establish the extent of commercialisation of NICANVEG indigenous vegetables among the women.

c. Investigate the challenges facing the commercialisation of the Nigeria-Canada indigenous vegetables project.

d. Determine the relationship between levels of participation in the training on NICANVEG indigenous vegetables project and extent of commercialisation of the product.

\section{METHODOLOGY}

The study used primary data. The population for the study comprised 1,200 women in 22 vegetables cooperative groups in the four Southwestern Nigeria states who participated in the project (Osun, Oyo, Ondo and Ekiti). Multistage sampling technique was used to select 390 project participants (300 for quantitative and 90 for qualitative) women for the study. Three states were selected using a simple random sampling technique out of the four states where the project took place between years 2011 and 2014. From each state, five Local Government Areas (LGAs) were selected using the simple random sampling technique. Thereafter, using a simple random sampling technique, two communities were selected in each LGA. From each community, 10 project women were selected using the convenience sampling technique. Another set of three participants were selected randomly in each community for focus group discussion. Two adapted instruments titled "Questionnaire on NICANVEG Project and Commercialisation (QNPC)" and "Interview on NICANVEG Project and Commercialisation” (INPC) were used to collect data from the participants. The instruments were dully validated and the reliability tests were conducted using Cronbach's Alpha and Spearman-Brown Split-half Coefficient. Internal consistency revealed the extent to which instrument items were homogenous and reflected the same underlying constructs. The results showed that QNPC and INPC yielded Cronbach's Alpha values of 0.78 and 0.81 and Spearman-Brown Split-half Coefficient values of 0.83 and 0.84 respectively. Also, data collected were analysed using percentages, relative significant index and chi-square statistical analyses. Qualitative data were collected on the three research questions. The data collected were transcribed and analysed using software package (Atlas ti). 


\section{RESULTS}

Research Question One: What is the perception of women toward the commercialisation of the NigeriaCanada indigenous vegetables project in Southwestern Nigeria?

Table-1. Perception of Women toward the Commercialisation of the Nigeria-Canada indigenous Vegetables Project in Southwestern Nigeria.

\begin{tabular}{lcc}
\hline Perception & Frequency(F) & Percent $(\mathbf{\%})$ \\
\hline Negative & 118 & 39.3 \\
Positive & 182 & 60.7 \\
Total & 300 & 100.0 \\
\hline
\end{tabular}

Source: Field survey, 2019.

Table 1 showed the perception of women toward the commercialisation of the Nigeria-Canada indigenous vegetables project. The results indicated that $182(60.7 \%)$ of the women expressed a positive perception towards the commercialisation of the product, while 118(39.3\%) of the participants had a negative perception towards the commercialisation of the Nigeria-Canada indigenous vegetables project. By these results, it is pertinent to state that most of the women who took part in the NICANVEG project supported the commercialisation of the product.

Qualitative Results on the Perception of women toward the commercialisation of the Nigeria-Canada indigenous vegetables.

Series of questions were thrown to the women about their perception of the commercialisation of the vegetables. For instance, women were asked whether have benefitted from the NICANVEG training programme? Most of the respondents indicated that training has equipped them with a better way of cultivating their vegetables. They were also asked whether they would like to put the skills and experiences gained from the training to practice. The positions were that a few of them believed that it might be impossible because of some perceived challenges. Others saw it as an avenue to boost their vegetables production. The participants were also asked whether they were prepared to shift from subsistence to full-scale cultivation of the NICANVEG indigenous vegetables. The responses of the women to this question differed. While few of the women saw it as not necessary, the majority of women believed that with the training and availability of the necessary assistance, they were ready to go into a large scale production of the indigenous vegetables.

From the above, it can be summarized that most women perceived it as very important to go into a full commercialisation of the vegetables.

Research Question Two: What is the extent of commercialisation of NICANVEG indigenous vegetables among the women?

\begin{tabular}{|c|c|c|}
\hline Level & Frequency(F) & Percent (\%) \\
\hline Subsistence & 25 & 8.3 \\
\hline Semi commercial & 41 & 13.7 \\
\hline Full Commercialisation & 234 & 78.0 \\
\hline Total & 300 & 100.0 \\
\hline
\end{tabular}

Source: Field survey, 2019.

From 2, the extent of involvement of women in the commercialisation of the grown Nigeria-Canada indigenous vegetables showed that $234(78.0 \%)$ of the women indicated that they have gone into full commercialisation of the under-utilised indigenous vegetables; 41(13.7\%) mentioned that they were practising semi-commercialisation and 25(8.3\%) indicated low level (subsistence) production. Arising from above, the results implied that the majority of 
the women who participated in the NICANVEG project training embraced full commercialisation of the indigenous vegetables.

Qualitative Results on the extent of commercialisation of the grown Nigeria-Canada indigenous vegetables among the participants

The participants were asked the extent of their commercialisation in the NICANVEG project. Although there were mixed responses from the women on the extent of their commercialisation of the vegetables. Some planted for commercial purposes while some could not go into full-scale production because they had limited funds. Most of the women affirmed that they planted vegetables for commercial purposes and sold them in bulk (wholesale). The participating women believed that before the training they received through the NICANVEG project, they were producing mostly for home consumption. However, since the introduction of the NICANVEG project, the opportunity they enjoyed had assisted them to embark on full commercialisation of indigenous vegetables. Although few of the women were still operating at subsistence level, some were operating both subsistence and commercial levels while the majority claimed that they were operating full commercialisation of the vegetables. In their responses, the women claimed that the project had helped them to be planting and supplying vegetables to many customers. They revealed that most of them that participated in the NICANVEG project now planted and sold vegetables to other people (retailers) who take the vegetables to the markets to sell.

In summary, the majority of the respondents interviewed on the extent of commercialisation of the NICANVEG project indicated that their involvement in the project had provided them with a better opportunity to go into full commercialisation of the under-utilised vegetables. While few of the women engaged in subsistence production; others indicated that they practised both subsistence and commercialisation, but most of them revealed that they were produced for commercial purposes.

Research Question Three: What are the challenges facing the commercialisation of the Nigeria-Canada indigenous vegetables project?

Table 3 showed the challenges being faced by the women in their effort to commercialise NICANVEG indigenous vegetables project. The highest among them were expensive farm equipment $(\bar{X}=3.57, \mathrm{RSI}=0.719)$, untimely fund $(\bar{X}=3.53 \mathrm{RSI}=0.711)$, poor market prices of vegetables $(\bar{X}=3.32, \mathrm{RSI}=0.666)$ and destruction of planted vegetables by pests and rodents $(\bar{X}=3.14$, RSI $=0.629)$. The least two challenges being faced by the vegetables farmers were not having enough experience on how to plant the vegetables $(\bar{X}=2.89, \mathrm{RSI}=0.581)$ and most of the seeds used for planting were of low quality $(\bar{X}=2.80$, RSI $=0.559)$. From the results, it is essential to mention that the challenges being faced in the women's bid to commercialise the vegetables were basically centred around inadequate financial support, lack of adequate infrastructure, inexperience and illiteracy of some of the women. These suggested that although the women actively participated in the projects, their post-training practices depended largely on the availability of basic infrastructural facilities such as good roads, access to good transportation, availability of financial support by the government and donor agencies, among others.

Qualitative Results on the Challenges Faced by the Participants' Women in the NICANVEG Project

According to the participants, they faced series of challenges in their bid to embark on the commercialisation of under-utilised indigenous vegetables. One of the challenges faced by the women is their inability to get financial assistance on time. They believed that money was a major problem for them. The participants explained that some of them had enough land where they could go into full commercialisation but there was not enough money to engage labour. The women noted that most of the labour they employed charged too much money before they could work on their farms. Apart from this major challenge, the participants mentioned challenges of getting fertilisers, 
pests' infection and lack of chemicals. The respondents submitted that the challenges did not allow them to produce a good yield. It limited their quantity and could not go into large-scale farming.

\begin{tabular}{|c|c|c|c|c|c|c|c|}
\hline Survey Items & $\begin{array}{c}\text { SA } \\
(\mathbf{N} / \%)\end{array}$ & $\begin{array}{c}\mathbf{A} \\
(\mathrm{N} / \%)\end{array}$ & $\begin{array}{c}\mathbf{D} \\
(\mathbf{N} / \%)\end{array}$ & $\begin{array}{c}\text { SD } \\
(\mathrm{N} / \%)\end{array}$ & $\bar{X}$ & RSI & Rank \\
\hline $\begin{array}{l}\text { The farm equipment is too expensive to } \\
\text { buy }\end{array}$ & $\begin{array}{c}14 \\
(4.7 \%)\end{array}$ & $\begin{array}{c}217 \\
(72.3 \%)\end{array}$ & $\begin{array}{c}6 \\
(2.0 \%)\end{array}$ & $\begin{array}{c}63 \\
(23.0 \%)\end{array}$ & 3.57 & 0.719 & $1^{\text {st }}$ \\
\hline $\begin{array}{l}\text { Fund is not timely made available to } \\
\text { participant women }\end{array}$ & $\begin{array}{c}20 \\
(6.7 \%)\end{array}$ & $\begin{array}{c}207 \\
(69.0 \%)\end{array}$ & $(0.7 \%)$ & $\begin{array}{c}71 \\
(23.7 \%)\end{array}$ & 3.53 & 0.711 & $2^{\text {nd }}$ \\
\hline Poor market prices of vegetable & $\begin{array}{c}12 \\
(4.0 \%)\end{array}$ & $\begin{array}{c}184 \\
(61.3 \%)\end{array}$ & $\begin{array}{c}4 \\
(1.3 \%)\end{array}$ & $\begin{array}{c}100 \\
(33.3 \%)\end{array}$ & 3.32 & 0.666 & $3^{\text {rd }}$ \\
\hline $\begin{array}{l}\text { Destruction of planted vegetables by } \\
\text { pests and rodents }\end{array}$ & $\begin{array}{c}24 \\
(8.0 \%)\end{array}$ & $\begin{array}{c}140 \\
(46.7 \%)\end{array}$ & $(0.3 \%)$ & $\begin{array}{c}135 \\
(43.0 \%)\end{array}$ & 3.14 & 0.629 & $4^{\text {th }}$ \\
\hline $\begin{array}{l}\text { Most of the harvested vegetables got } \\
\text { spoilt while waiting to be taking to the } \\
\text { market }\end{array}$ & $\begin{array}{c}20 \\
(6.7 \%)\end{array}$ & $\begin{array}{c}111 \\
(37.0 \%)\end{array}$ & $\begin{array}{c}57 \\
(19.0 \%)\end{array}$ & $\begin{array}{c}112 \\
(37.3 \%)\end{array}$ & 3.12 & 0.626 & $5^{\text {th }}$ \\
\hline $\begin{array}{l}\text { Not having enough money to buy some } \\
\text { farming equipment }\end{array}$ & $\begin{array}{c}11 \\
(3.7 \%)\end{array}$ & $\begin{array}{c}149 \\
(49.7 \%)\end{array}$ & $\mathrm{O}(\mathrm{O} \%)$ & $\begin{array}{c}140 \\
(46.6 \%)\end{array}$ & 3.07 & 0.618 & $6^{\text {th }}$ \\
\hline $\begin{array}{l}\text { There are not good access roads for } \\
\text { easy transportation of harvested } \\
\text { vegetables from the farm to the market }\end{array}$ & $\begin{array}{c}14 \\
(4.7 \%)\end{array}$ & $\begin{array}{c}115 \\
(38.3 \%)\end{array}$ & $(0.3 \%)$ & $\begin{array}{c}170 \\
(56.7 \%)\end{array}$ & 2.89 & 0.581 & $7^{\text {th }}$ \\
\hline $\begin{array}{l}\text { Flooding in the vegetable farm at the } \\
\text { inception of rain }\end{array}$ & $\begin{array}{c}20 \\
(6.7 \%)\end{array}$ & $\begin{array}{c}93 \\
(31.0 \%)\end{array}$ & $(0.3 \%)$ & $\begin{array}{c}186 \\
(62.0 \%)\end{array}$ & 2.80 & 0.559 & $8^{\text {th }}$ \\
\hline $\begin{array}{l}\text { Not having enough land to plant the } \\
\text { vegetables }\end{array}$ & $\begin{array}{c}17 \\
(5.7 \%)\end{array}$ & $\begin{array}{c}93 \\
(31.0 \%)\end{array}$ & $\begin{array}{c}0 \\
(0 \%)\end{array}$ & $\begin{array}{c}190 \\
(64.4 \%)\end{array}$ & 2.74 & 0.555 & $9^{\text {th }}$ \\
\hline $\begin{array}{l}\text { People are not treating women farmers } \\
\text { well }\end{array}$ & $\begin{array}{c}8 \\
(2.7 \%)\end{array}$ & $\begin{array}{c}98 \\
(32.7 \%)\end{array}$ & $(0.3 \%)$ & $\begin{array}{c}193 \\
(64.3 \%)\end{array}$ & 2.71 & 0.545 & $10^{\text {th }}$ \\
\hline $\begin{array}{l}\text { Have problem of how to read and write } \\
\text { (illiteracy) }\end{array}$ & $(0.7 \%)$ & $\begin{array}{c}75 \\
(25.0 \%)\end{array}$ & $\begin{array}{c}\mathrm{O} \\
(\mathrm{O} \%)\end{array}$ & $\begin{array}{c}223 \\
(74.3 \%)\end{array}$ & 2.50 & 0.500 & $11^{\text {th }}$ \\
\hline $\begin{array}{l}\text { Not having enough experience on how } \\
\text { to plant the vegetables }\end{array}$ & $\begin{array}{c}5 \\
(1.7 \%)\end{array}$ & $\begin{array}{c}57 \\
(19.0 \%)\end{array}$ & $\begin{array}{c}4 \\
(1.3 \%)\end{array}$ & $\begin{array}{c}234 \\
(78.0 \%)\end{array}$ & 2.42 & 0.485 & $12^{\text {th }}$ \\
\hline $\begin{array}{l}\text { Most of the seeds used for planting are } \\
\text { of low quality }\end{array}$ & $(0.7 \%)$ & $\begin{array}{c}34 \\
(11.3 \%)\end{array}$ & $(0.3 \%)$ & $\begin{array}{c}263 \\
(87.6 \%)\end{array}$ & 2.24 & 0.449 & $13^{\text {th }}$ \\
\hline
\end{tabular}

Table-4. Relationship between levels of participation in the training on NICANVEG Indigenous vegetables project and extent

\begin{tabular}{|c|c|c|c|c|c|c|c|}
\hline \multirow[t]{2}{*}{ Level of Participation } & \multicolumn{7}{|c|}{ Extent of Commercialisation } \\
\hline & Low & Moderate & Full & Total & $\chi^{2}$ & & $\mathrm{p}$ value \\
\hline \multirow[t]{2}{*}{ Low } & 6 & 9 & 10 & 25 & & & \\
\hline & $2 \%$ & $3 \%$ & $3.3 \%$ & $8.3 \%$ & & & \\
\hline \multirow[t]{2}{*}{ Average } & 5 & 8 & 11 & 23 & & & \\
\hline & $1.7 \%$ & $2.6 \%$ & $3.7 \%$ & $7.6 \%$ & 111 & 865 & .000 \\
\hline \multirow[t]{2}{*}{ High } & 7 & 11 & 233 & 252 & & & \\
\hline & $2.3 \%$ & $3.7 \%$ & $77.7 \%$ & $84.0 \%$ & & & \\
\hline \multirow[t]{2}{*}{ Total } & 18 & 28 & 254 & 300 & & & \\
\hline & $6.0 \%$ & $9.3 \%$ & $84.6 \%$ & $100.0 \%$ & & & \\
\hline
\end{tabular}

It can be inferred from the responses of the women interviewed on the challenges faced by the participants' women in the NICANVEG project that several challenges were being faced by the women who took part in the production of under-utilised indigenous vegetables. Among the challenges was lack of enough capital which had hindered them from buying some of the needed equipment. Others were poor storage facilities (which made some of the vegetables to be affected by pests, rodents or diseases), lack of water (especially during dry season), high cost of labour as well as a high cost of seedlings which were posing threat to better performance of some of the women farmers to cultivate under-utilised indigenous vegetables. 
Hypothesis One: There is no a significant relationship between levels of participation in the training on NICANVEG indigenous vegetables project and extent of commercialisation of the product.

The Table 4 revealed a significant relationship between levels of participation in the training on NICANVENG indigenous vegetables project and the extent of commercialization of the product $\left(\chi^{2}=111.865, \mathrm{p}<\right.$ 0.05). This implies that levels of participation in the training have a significant relationship with the extent of commercialisation of the vegetables.

\section{DISCUSSION OF FINDINGS}

Quite a number of findings have emerged from the results above. One of the findings was that most of the women who took part in the NIVANVEG project training had a positive perception towards the commercialisation of the indigenous vegetables. It was revealed from the study that with the skills and knowledge acquired, the farmers were ready to embrace the market-oriented cultivation of the product. The above finding was evidently supported by the attitude of the women to vegetables cultivation after the NICANVEG training. For instance, the report of the study conducted by Akinfaye (2013) revealed that women in Osun State participated more in vegetables production. The above result was supported by Adebooye, Deji, Ayanwale, Oyedele, and Alao (2014) that the introduction of the NICANVEG project, has re-packed participating farmers toward the adoption of a range of technologies, including seedbed preparation, seed treatment to prevent soil-borne diseases and pests, seed planting rate, reduction of germination period and botanical pest control which have improved the yield of indigenous vegetables. Contrarily, Edeoghon (2016) showed that despite the importance of the indigenous vegetables, some farmers still displayed a negative attitude towards the large-scale production of the vegetables. To him, women were still cultivating vegetables on the small-scale using traditional techniques. Nonetheless, it can be established the introduction of the NICANVEG project has really equipped the women in modern technologies of cultivating under-utilised indigenous vegetables. The results also revealed that the extent to which women participants in the NICANVEG project was at full commercialisation. It was revealed that in spite of the constraints that the participating women were facing, they were still operating at the level of full commercialisation. For instance, findings showed that the commercialisation of indigenous vegetables were given full attention among the women in southwestern Nigeria. The finding was supported by Ele et al. (2013) that the extent of commercialisation of vegetables in the Southern part of Nigeria was moderately high. However, the finding was at variance with that of Edeoghon (2016) study that commercialisation of indigenous vegetables was given less attention in Nigeria. Bye and large, the enthusiastic attitude of women involved in the NICANVEG project was as a result of the acquired skills from the NICANVEG project which has compensated for their educational deprivation and equipped them to successfully embark on full-scale production. Findings revealed that factors such as expensive farm equipment, untimely fund, poor market prices of vegetable and destruction of planted vegetables by pests and rodents were some of the challenges faced by the women in the NICANVEG project. The findings were in-line with Mary (2007) that listed poor seed quality, pests and diseases, drought, poor marketing channels, transport to markets, lack of agronomic and utilisation packages were among the major constraints that hinder the optimal production of African leafy vegetables. In their own study, Deji et al. (2012) identified non-availability of land, inadequate inputs, lack of extension contact, transportation, storage and high cost of input as constraints facing men and women vegetable farmers. Pandit and Basak (2013) study established that low price of vegetables, lack of quality seed and high wages of labourer were the most prevailing constraints to mass production of indigenous vegetables. Also, Muriithi and Matz (2015) corroborated the findings by citing high costs of inputs, unskilled labour, weather risks and erratic vegetable prices as the major constraints to women full participation in the commercialisation of under-utilised 
indigenous vegetables. Arising from above, it is pertinent to state that the major challenges that were common to the indigenous vegetable farmers were poor storage, poor funding, poor marketing price and incessant pests and diseases. Above all, the finding from the study revealed a significant relationship between the levels of participation in the NICANVEG project and extent of commercialisation of indigenous vegetables. This implies that the participants who actively took part in the training and the enlightenment programme of the project had the opportunity of being exposed to the new technologies of production and this has afforded them to shift from subsistence farming of indigenous vegetables to a more market-oriented system of cultivation which is known as commercialisation.

\section{CONCLUSION/RECOMMENDATIONS}

It can be concluded from the study above that most women who actively participated in the training on NICANVEG indigenous vegetables project developed a positive perception towards the commercialisation of the indigenous vegetables. Also, it was concluded from the study that as a result of their positive disposition to the project, most of the women shifted from subsistence farming of the vegetables to full-scale production.

Arising from the conclusion, it is recommended that the government and other stakeholders can assist farmers by providing constant agricultural extension services to women farmers. This will help them to acquire technical know-how that can assist them in their agricultural practices. Also, farming activities can be improved through the provision of some incentives and farm equipment to farmers. Lastly, it is recommended that farmers should always make better use of the opportunities available to them any time such opportunities are given to them.

\section{REFERENCES}

Acha, C. K. (2014). Trend and levels of women empowerment in Nigeria. American Journal of Applied Mathematics and Statistics, 2(6), 402-408. Available at: https://doi.org/10.12691/ajams-2-6-8.

Adebooye, O. C., Deji, O. F., Ayanwale, A. B., Oyedele, D. J., \& Alao, T. O. (2014). Stories of change: Nigerian women reap benefits from indigenous vegetables. Reports on Research Supported by the Canadian International Food Security Research Fund (CIFSRF), A Program of Canada's International Development Research Centre (IDRC).

Adelani, A. O., Olajide-Taiwo, F., Adeoye, I., \& Olajide-Taiwo, L. (2011). Analysis of production constraints facing Fadama vegetable farmers in Oyo State, Nigeria. World Journal of Agricultural Sciences, 7(2), 189-192.

Agboola, B. O. (2001). Dry season farming: Tapping agricultural resources in Remo North Local Government Area of Ogun State (pp. 16-18): OGADEP Venture.

Akinfaye, T. S. (2013). Analysis of the involvement of rural men and women in vegetable production in Osun State Nigeria. Unpublished B.Sc Thesis Submitted to the Department of Agricultural Extension and Rural Development, Obafemi Awolowo University. Ife.

Anon, C. (2006). Nigeria fertilizer strategy report. Paper presented at the Africa Fertilizer Summit, International Conference Centre, Abuja, 9-16th June, 2006.

CBN. (2006). Central bank of Nigeria annual report and statement of account publication for the year ending 2005 (Vol. CBN): Abuja Nigeria.

Deji, O. F., Koledoye, G. F., \& Owombo, P. T. (2012). Gender analysis of constraints to vegetable production in Ondo State, Nigeria. Paper presented at the 21 st Annual National Congress of the Nigerian Rural Sociological Association (NRSA) held at University of Ibadan between Sunday, 7th and Thursday, 11 th October 2012.Ibadan.

Edeoghon, C. (2016). An assessment of urban women participation in vegetable production in Ovia North East Local Government Area of Edo State, Nigeria. Journal of Agriculture and Veterinary Science (IOSR-JAVS), 9(7), 30-35. 
Ele, I., Omini, G., \& Adinya, B. (2013). Assessing the extent of commercialization of smallholding farming households in Cross River State, Nigeria. Journal of Agriculture and veterinary Science, 4(3), 49-55. Available at: https://doi.org/10.9790/2380-0424955.

FAO. (2010a). Gender equality. Rome: FAO.

FAO. (2010b). Gender equality. Rome: FAO.

Immink, M. D. C., \& Alacorn, J. A. (1993). Household income, food availability and commercial crop production by smallholder farmers in the Western Highlands of Guatemala. Economic Development and Cultural Change, 41(2), 319-342.

International Development and Research Centre (IDRC). (2014). Promotion of underutilized indigenous food resources for food security and nutrition in Asia and the Pacific. Food And Agriculture Organization of the United Nations Regional Office For Asia And The Pacific Bangkok.

Leavy, J., \& Poulton, C. (2007). Commercialisations in agriculture. Ethiopian Journal of Economics, 16(1), 1-37.

Lyatuu, E., Msuta, G., Sakala, S., Marope, M., Safi, K., \& Lebotse, L. (2009). Marketing of indigenous leafy vegetables and how smallscale farmers' income can be improved in SADC region (Tanzania, Zambia and Botswana). Paper presented at the Marketing Information, Project under SADC-ICART Project -2009 .

Mahelet, G. F. (2007). Factors affecting commercialization of smallholder farmers in Ethiopia: The case of North Omo Zone, SNNP region. Paper presented at the In Fifth International Conference on the Ethiopian Economy, Addis Ababa.

Mary, A. O. (2007). The diversity of cultivated African leafy vegetables in three communities in Western Kenya. African Journal of Food Agriculture Nutrition and Development, 7(3), 1-15.

Muriithi, B. W., \& Matz, J. A. (2015). Welfare effects of vegetable commercialization: Evidence from smallholder producers in Kenya. Food Policy, 50, 80-91. Available at: https://doi.org/10.1016/j.foodpol.2014.11.001.

National Bureau of Statistics. (2014). National bureau of statistics report. Abuja: NBS.

Nizamuddin, K., Salman, S., \& Rehman, A. (2009). Vegetable revolution and rural sustainable development: A case study. Journal for Geography, 4(1), 175-188.

Okezie, C., Nwosu, A., \& Okezie, C. (2008). An assessment of the extent of the commercialization of agriculture in Abia State. Nigeria. Agricultural Journal, 3(2), 129-133.

Olwande, J., Smale, M., Mathenge, M. K., Place, F., \& Mithöfer, D. (2015). Agricultural marketing by smallholders in Kenya: A comparison of maize, kale and dairy. Food Policy, 52, 22-32. Available at: https://doi.org/10.1016/j.foodpol.2015.02.002.

Pandit, J., \& Basak, N. (2013). Constraints faced by the farmers in commercial cultivation of vegetables. Journal of the Bangladesh Agricultural University, $11(2)$, 193-198. Available at: https://doi.org/10.3329/jbau.v11i2.19893.

Sabo, E., \& Dia, Z. Y. (2009). Awareness and effectiveness of vegetable technology information packages by vegetable farmers in Adamawa State, Nigeria. African Journal of Agricultural Research, 4(2), 065-070.

Shiundu, K. M., \& Oniang'o, R. K. (2007). Marketing African leafy vegetables: Challenges and opportunities in the Kenyan context. African Journal of Food Agriculture Nutrition and Development, 7(4), 1-17.

Sokoni, C. H. (2007). Commercialisation of smallholder production in Tanzania: Implications to sustainable resources management. Paper presented at the Paper Presented at the Workshop on Resource Management and Sustainable Development: White Sands Hotel, Dar es Salaam.

World Bank. (2007). Global monitoring report 2007: Confronting the challenges of gender equality and fragile states. Washington, DC: World Bank.

Online Science Publishing is not responsible or answerable for any loss, damage or liability, etc. caused in relation to/arising out of the use of the content. Any queries should be directed to the corresponding author of the article. 